\title{
Effective Marketing Strategies to Attract Business Visitors at Trade Shows
}

\author{
Mei-Chin $\mathrm{Chu}^{1} \&$ Sui-Ming Chiu ${ }^{1}$ \\ ${ }^{1}$ Department of International Business, Southern Taiwan University of Science and Technology, Taiwan \\ Correspondence: Mei-Chin Chu, Department of International business, Southern Taiwan University of Science \\ and Technology, Tainan, Taiwan. E-mail: mcchu@mail.stut.edu.tw
}

Received: October 8, 2013

Accepted: October 25, $2013 \quad$ Online Published: November 20, 2013

doi:10.5539/ijbm.v8n24p64

URL: http://dx.doi.org/10.5539/ijbm.v8n24p64

\begin{abstract}
Trade shows have been the focus of recent research as constituting one of the most effective marketing strategies. Related issues have been discussed extensively in the literature. How to achieve better performance is central to these discussions. Studies on the key factors that influence trade show performance have focused mainly on subjective opinions from the perspective of the staff at exhibitions. In this study, we explored the key criteria for a business visitor in selecting suppliers at a trade show; that is, what kind of trade show strategies can promote exhibitors' performance? Trade show strategies from previous studies were first summarized. They were classified into three categories: before, at, and after the show. To address the problem of complexity and uncertainty, a fuzzy analytic hierarchy process (FAHP) was used to explore the importance of the various strategies. The results showed that "follow-up after the exhibition" was the most important factor from the perspective of business visitors. "Active invitation before the exhibition" was considered to be the next most important issue in attracting business visitors at a trade show. Among at-show strategies, the most important was that of staff knowledge of the product and trade details. The results of this study could contribute to enhancing trade show performance.
\end{abstract}

Keywords: trade show strategies, trade-show performance, FAHP

\section{Introduction}

Trade shows, also called trade fairs, trade exhibitions, or expos, have been considered an effective strategy in business marketing. The average cost of making a face-to-face contact with potential and current customers at a trade show is much lower than the cost of a personal sales visit (Bellizzi \& Lipps, 1984; Bello, 1992; Bello \& Ritu, 1993). Trade shows also provide a means for companies to enter a new market at relatively low cost (O'Hara, Palumbo \& Herbig, 1993). Literature reports also indicate that trade shows provide an opportunity for smaller enterprises to compete with larger firms (Tanner, 2002). As a result, trade shows have become a popular means of sales promotion for export-oriented companies and for small- and medium-sized enterprises (Browing \& Adams, 1998).

Tanner and Chonko (1995) indicated that the main objective of trade show exhibitors was sales (about 62\%), followed by generating new business, increasing sales, fostering new and servicing established relationships, brushing up on industry contacts, and sizing up the competition. All of these things unfold at trade shows. Yao (2007) further divided the goals of trade show exhibitors into two categories: sales objectives (such as making direct sales and finding local sales representatives) and non-sales objectives (including building brand/image, maintaining contact with former/new customers, improving corporate image, gathering competitor information). Although trade shows might not directly affect sales immediately, previous studies have shown that non-sales objectives, such as brand/image building and customer and public relationship maintenance, influence the future purchasing decision of business visitors at trade shows. That is, non-sales activities at a trade show might affect the decisions of potential buyers in the long run. Thus, the sales performance effects can last over a longer period of time than the show itself.

Many studies have indicated that trade show strategies can be divided into three stages: before, during, and after the show. For example, setting objectives before participating in shows (Kerin \& Cron, 1987; Gadar \& O'Connor, 2001; Tanner, 2002; Lee \& Kim, 2008), choosing adequate locations and booth size, and selecting the materials to display (Li, 2006; Lee \& Kim, 2008; Kerin \& Cron, 1987) are all key factors in trade show 
performance. However, orders placed by buyers at trade shows tend to be trial orders. Most transactions will be finalized based on subsequent follow-up actions after shows.

Many exhibitors in Taiwan are small-and medium-sized enterprises. For such enterprises, which have fewer resources than larger companies, the question of how to effectively achieve better trade show performance is a vital issue. A number of relevant issues have been discussed regarding trade show performance; financial benefits are usually the core of the discussion. However, a great deal of complexity in the measurement of trade show performance is involved because of the many tangible versus non-tangible and measurable versus non-measurable factors, which all mix together. Furthermore, vagueness and uncertainty increase the difficulty of any analysis. The main objective of this study was to establish an effective framework for evaluating the relative importance of the strategies used at trade shows.

Although visitors at trade shows include buyers, potential buyers, and non-business visitors, the question of how to attract buyers and potential buyers is the most crucial issue for exhibitors at a trade show. Thus, this research was designed from the perspective of business buyers. Promotional activities at a trade show that will influence visitors' purchasing decisions were explored. The study subjects consisted of staff members who both make purchasing decisions regularly or have influence on purchases within their company, and are authorized to make purchases at or after shows.

\section{Literature Review}

Wikipedia (2013) defines a trade show as: "An exhibition organized so that companies in a specific industry can showcase and demonstrate their latest products and services, study activities of rivals and examine recent market trends and opportunities." The event has two features: a defined time frame and is held periodically. A trade show aims to match interests among the organizers, exhibitors, and visitors and, thus, Kotler (2000) classified trade shows as constituting a means of sales promotion.

Trade shows are usually organized by governments, chambers of commerce, industry associations, or specialized exhibition companies. They can be classified into the following types according to their characteristics (Wen \& Duan, 2008).

- By origin of participants: international, national, regional, and local trade shows. They range from large to small areas according to origin of exhibitors and visitors.

- By range of goods offered: including universal/general, special interest, and industry-specific trade shows (Gopalakrishna \& Williams, 1992).

- By audience: including business-to-business (B2B) and business-to-customer (B2C) shows. Consumer fairs are open to the public, while others can only be attended by company representatives and the press; thus, trade shows can be classified as "public" or "trade only".

This study mainly focused on B2B shows. Business participants at trade shows include domestic and international manufacturers, foreign traders, and trading agents. Firms use various strategies to promote their sales. A clear and feasible objective should be clearly defined in making effective show marketing strategies (Wen \& Duan, 2008; Gopalakrishna, Lilien, Williams \& Sequeira, 1995; Herbig, Palumbo \& O’Hara, 1996).

The objectives of exhibitors at trade shows can be classified into selling and non-selling objectives, such as gathering information about the marketplace, getting customer feedback on products, identifying potential buyers and/or representatives, learning more about the competition and the products they have to offer, and taking orders for and/or selling products (Bonoma, 1983; Jackson, Keith \& Burdick, 1987; Sharland \& Balogh, 1996; Yao, 2007; Wen \& Duan, 2008). Tanner and Chonko (1995) found that promoting sales was listed as the top objective for firms participating in trade shows.

Studies of trade show performance measures have tended to emphasize observational indicators such as actual sales at the show, number of leads, and attraction efficiency (i.e., percentage of a firm's target audience attracted to its booth) (Teng \& Tzeng, 1993; Dekimpe, Francois, Gopalakrishna \& Bulte, 1997; Gopalakrishna \& Williams, 1992; Gopalakrishna \& Lilien, 1995; Kerin \& Cron, 1987). However, Hansen (2004) claimed that many of these studies failed to legitimize those claims with a clear definition of the domain being measured or to provide evidence of validity.

As noted above, sales-related marketing activities of trade shows can be classified into three stages: pre-, at-, and post-show. Table 1 lists trade strategies pertaining to these three stages that can influence the decision-making of business visitors. 
Table 1. Marketing strategies pertaining to the three stages of trade shows

\begin{tabular}{|c|c|c|}
\hline Stage & Objective of marketing strategy & Reference \\
\hline Pre-show & $\begin{array}{l}\text { How to deliver trade show information to potential visitors, such as } \\
\text { sending invitations, advertising, or news releases. }\end{array}$ & $\begin{array}{l}\text { Seringhaus \& Rosson (2001); } \\
\text { Tanner (2002); } \\
\text { Lee \& Kim (2008) } \\
\end{array}$ \\
\hline At-show & $\begin{array}{l}\text { Strategies to attract business visitors, including arrangement of booth, } \\
\text { product display, and staff reception. }\end{array}$ & $\begin{array}{l}\text { Gopalakrishna \& Lilien (1995); Rosson \& } \\
\text { Seringhaus (1995); } \\
\text { Seringhaus \& Rosson (2001); } \\
\text { Li (2007); Lee \& Kim (2008); Kerin \& } \\
\text { Cron (1987) }\end{array}$ \\
\hline Post-show & $\begin{array}{l}\text { Follow-up after shows to establish business relationships with business } \\
\text { visitors, such as sending sales letters \& samples, or making personal } \\
\text { visits. }\end{array}$ & $\begin{array}{c}\text { Tanner (2002); } \\
\text { Su (2004); Lee \& Kim (2008) }\end{array}$ \\
\hline
\end{tabular}

Most of the studies referenced in Table 1 focused on at-show marketing strategies. Table 2 presents details of the strategies used at shows and their related attributes.

Table 2. At-show strategies that can influence business visitors' decisions

\begin{tabular}{ccc}
\hline Strategy & Attributes & Reference \\
\hline $\begin{array}{c}\text { Booth } \\
\text { arrangement }\end{array}$ & Accessibility, size, design, and news releases & Gopalakrishna \& Lilien (1995); \\
Seringhaus \& Rosson (2001); \\
Li (2007); Lee \& Kim (2008);
\end{tabular}

As shown in Tables 1 and 2, many strategies can be used in trade shows. However, the problem that must be solved concerns the question of which of these strategies to focus on, particularly when resource availability is a major concern for a company. The main objective of this study was to evaluate the importance of trade show strategies from the viewpoint of business buyers making decisions regarding supplier selection. On the basis of the literature, strategies were grouped into three categories: pre-, at-, and post-show.

\section{Research Methodology}

To obtain overall priority values of business visitors in selecting suppliers at trade shows, a fuzzy multi-attribute decision-making method was used (Tseng \& Lin, 2008). First, owing to its multi-objective nature (Shoham, 1992; Munuera, 1999), an analytical hierarchy process (AHP) was undertaken to set up the hierarchy framework for the research (Saaty, 1980). Using this AHP structure, we designed a questionnaire to collect data on supplier selection from business visitors at trade shows. Fuzzy theory was then used to reflect the ambiguity of the decision-making process (Zadeh, 1965; Dubious \& Prade, 1978; Laarhoven \& Pedryce, 1983). This method, referred to as the fuzzy analytical hierarchy process (FAHP), has been widely used as an analytical tool to reflect the inherent imprecision involved in the survey process.

The present study was based on an expert survey regarding marketing strategy prioritization at trade shows. The AHP framework, illustrated in Figure 1, was used to design the questionnaire. 


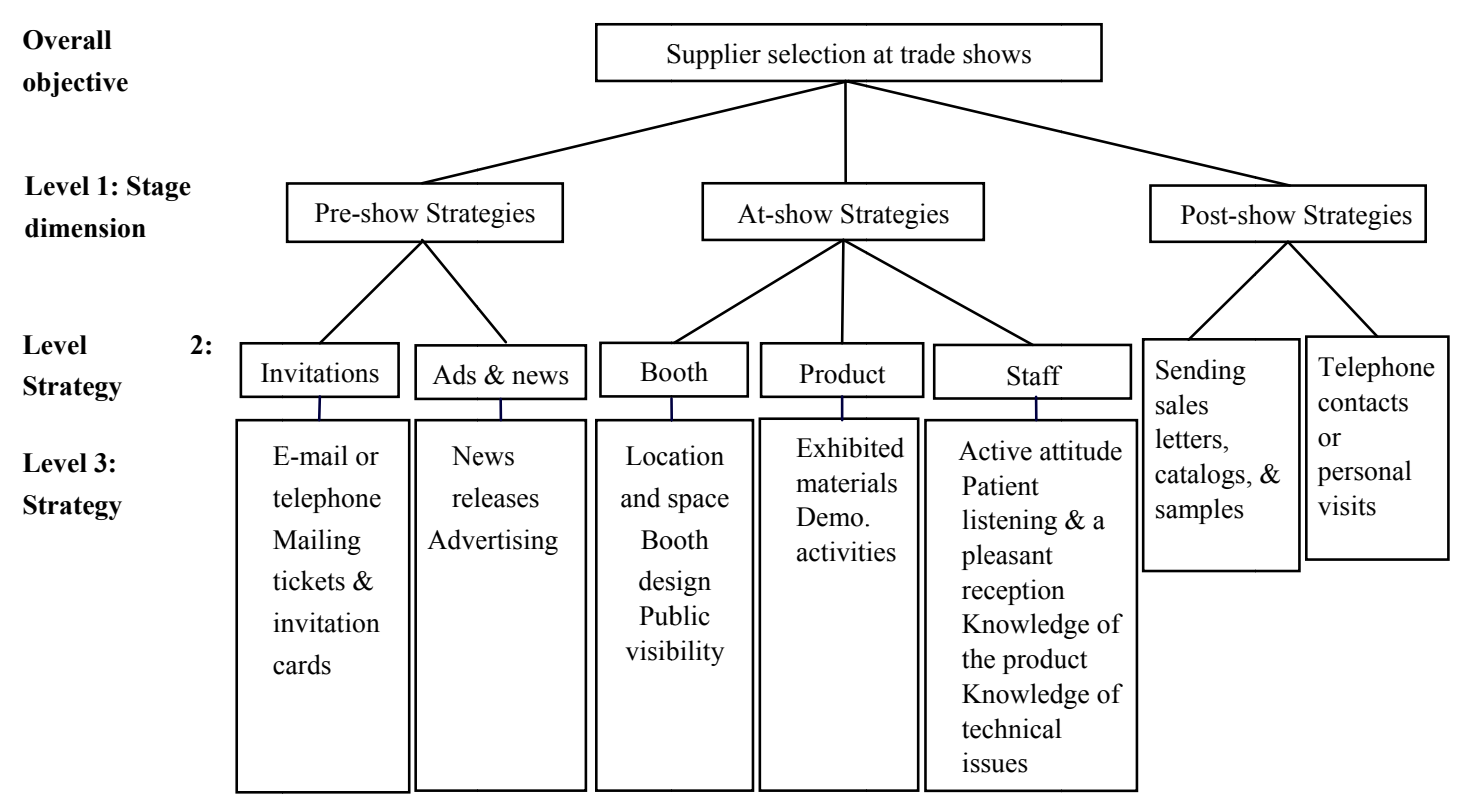

Figure 1. Hierarchical structure of trade show strategies

There were three hierarchical levels in the framework. Under the overall objective, sales-related activities were classified into the pre-, at-, and post-show stages in hierarchical Level 1. Level 2 and Level 3 included the detailed strategies and related attributes.

These strategies were evaluated in terms of their importance, based on experts' judgments. A pair-wise comparison process was used to elicit expert opinions regarding the importance of trade show strategies. Table 3 is an example of the questionnaire design.

Table 3. Example of the questionnaire design

\begin{tabular}{|c|c|c|c|c|c|c|c|c|}
\hline \multicolumn{9}{|c|}{ Level 1, “When selecting suppliers, which strategy dimension is more important at a trade show?" } \\
\hline \multicolumn{4}{|c|}{ Pre-show dimension } & \multirow{2}{*}{$\begin{array}{l}\text { Or } \\
\square\end{array}$} & \multicolumn{4}{|c|}{ At-show dimension } \\
\hline$\square$ & $\square$ & $\square$ & $\square$ & & $\square$ & $\square$ & $\square$ & $\square$ \\
\hline $\begin{array}{l}\text { Extremely } \\
\text { important }\end{array}$ & & $\begin{array}{c}\text { Greatly } \\
\text { important }\end{array}$ & 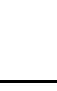 & $\begin{array}{l}\text { Equally } \\
\text { important }\end{array}$ & & $\begin{array}{c}\text { Greatly } \\
\text { important }\end{array}$ & - & $\begin{array}{l}\text { Extremely } \\
\text { important }\end{array}$ \\
\hline
\end{tabular}

This study used a nine-point scale to evaluate the score of each question. For "equally important," "moderately important," "greatly important," "very greatly important," and "extremely important," values of 1, 3, 5, 7, and 9 were assigned, respectively, and 2, 4, 6, and 8 were assigned to intermediate values between two adjacent judgments. The level of importance was scaled according to Buckley (1985).

Fuzzy theory was further used to reflect the ambiguity of the decision-making process. The conversion scale was made using the method developed by Laarhoven and Pedryce (1983), based on the studies of Zadeh (1965) and Dubious and Prade (1978), as in Table 4.

Table 4. Linguistic language and triangular fuzzy conversion scale

\begin{tabular}{lcc}
\hline \multicolumn{1}{c}{ Linguistic language } & Quantitative value & Triangular fuzzy scale \\
\hline Equally important & 1 & $1=(1,1,1)$ \\
Moderately important & 3 & $3=(2,3,4)$ \\
Greatly important & 5 & $5=(4,5,6)$ \\
Very greatly important & 7 & $7=(6,7,8)$ \\
\hline
\end{tabular}




\begin{tabular}{lcc}
\hline Extremely important & 9 & $9=(8,9,10)$ \\
Intermediate values & $2,4,6,8$ & $2=(1,2,3) ; 4=(3,4,5)$ \\
\hline
\end{tabular}

The analytical procedure was as follows:

1) Construct the hierarchy: based on existing research, set up the evaluation framework for supplier selection.

2) Pair-wise comparisons of the importance of show strategies: comparing strategies two by two in the hierarchy to incorporate respondents' judgments about the various elements.

3) Build triangular fuzzy numbers: to reflect the imprecision in judgments based on human perception, triangular fuzzy numbers were used.

$$
\alpha_{i j}=\left(\alpha_{i j}, b_{i j}, c_{i j}\right)_{L-R}
$$

4) Establish fuzzy pair-wise comparative matrix.

5) Integrate opinions of experts in fuzzy numbers, using Buckley's (1985) average method.

$$
\tilde{\alpha}_{i j}=(1 / N) \otimes\left(\tilde{\alpha}_{i j}{ }^{1} \oplus \tilde{\alpha}_{i j}{ }^{2} \oplus \ldots \ldots . \tilde{\alpha}_{i j}{ }^{N}\right)
$$

6) Compute fuzzy weight system of the framework.

$$
\begin{gathered}
\tilde{Z}_{i}=\left(\tilde{\alpha}_{i 1} \otimes \tilde{\alpha}_{i 2} \otimes \ldots \ldots . \tilde{\alpha}_{i n}\right)^{1 / n}, \forall_{i}=1,2, \ldots, n \\
\tilde{W}_{i}=\tilde{Z}_{i} \otimes\left(\tilde{Z}_{1} \oplus \tilde{Z}_{2} \oplus \ldots \ldots . \oplus \tilde{Z}_{n}\right)^{-1}, \forall_{i}=1,2, \ldots \ldots, n
\end{gathered}
$$

7) Adjust the framework: using the center of gravity method, de-fuzz the criteria (Teng \& Tzeng, 1993); then normalize to a crisp value.

$$
d F_{i j}=\frac{\left[\left(R_{i j}-L_{i j}\right)+\left(M_{i j}-L_{i j}\right)\right]}{3}+L_{i j}
$$

8) Integrate the hierarchy to obtain a ranking of all elements.

$$
W_{k}=W_{i} \times W_{i p} \times W_{i p k}
$$

\section{Results and Discussion}

Eight experts from different companies were selected for this study. They were staff who regularly made purchasing decisions for a company and had experience in making procurements through visiting trade shows. All of them were top managers in their companies and most of them (87.5\%) had at least 10 years of work experience. Half of them were from trading companies, whereas the rest were from manufacturing-based companies.

The results of the analysis are listed in Tables 5 and 6 . In the first hierarchy of the analysis, post-show strategies (0.554) were the most important factor affecting trade show buyers, followed by at-show strategies $(0.279)$ (Table 5).

Table 5. Fuzzy weight and the rank of the first hierarchical level

\begin{tabular}{lccc}
\hline Stage & Triangular fuzzy value & Fuzzy weight & Rank \\
\hline Pre-show & $0.163,0.166,0.174$ & 0.168 & 3 \\
At-show & $0.281,0.274,0.280$ & 0.279 & 2 \\
Post-show & $0.556,0.560,0.546$ & 0.554 & 1 \\
\hline
\end{tabular}

In the category of "pre-show marketing," sending invitations (0.704) was more important than advertising (0.296). For at-show strategies, professional competence of the staff (0.531) was the most important factor. Personal visits were more effective than sending sales letters. In the category of "at-show marketing", ranking in terms of importance was staff, booth, and product, in that order (Table 6). 
Table 6. Fuzzy weight and the rank of the second hierarchical level

\begin{tabular}{ccccc}
\hline Stage & Strategy & Triangular fuzzy value & Fuzzy weight & Rank \\
\hline \multirow{2}{*}{ Pre-show } & Invitation & $0.706,0.710,0.695$ & 0.704 & 1 \\
& Advertising & $0.294,0.290,0.305$ & 0.296 & 2 \\
\hline \multirow{2}{*}{ At-show } & Booth arrangement & $0.256,0.258,0.254$ & 0.256 & 0.213 \\
& Product display & $0.215,0.213,0.212$ & 0.531 & 1 \\
& Staff reception & $0.530,0.528,0.534$ & 0.391 & 2 \\
\hline \multirow{2}{*}{ Post-show } & Sales letters & $0.384,0.396,0.393$ & 0.609 & 1 \\
\hline
\end{tabular}

"At-show marketing" has been a focus of interest from both academic and practical perspectives and, thus, Table 7 lists the values evaluated and ranks of the strategies under booth, product, and staff dimensions. In terms of booth factors, public visibility (0.376) was the most important strategy, followed by impressive booth design (0.363). For the product dimension, booth activities and demonstrations $(0.530)$ were listed as constituting the most important factor. Regarding exhibition staff, ability to answer questions about the product, technology, and trade details were listed as constituting the most important factor.

Table 7. Fuzzy weight and the rank of attributes for each at-show strategy

\begin{tabular}{cccc}
\hline Strategy details & Triangular fuzzy value & Fuzzy weight & Rank \\
\hline Booth arrangement & & & \\
Location and space & $0.264,0.261,0.260$ & 0.262 & 3 \\
Booth design & $0.372,0.357,0.359$ & 0.363 & 2 \\
Public visibility & $0.364,0.382,0.381$ & 0.376 & 1 \\
\hline Product display & & & \\
Exhibited materials & $0.472,0.467,0.472$ & 0.470 & 2 \\
Demonstration activities & $0.528,0.533,0.528$ & 0.530 & 1 \\
Staff reception & & & 5 \\
Active attitude & $0.088,0.086,0.088$ & 0.087 & 4 \\
Patient and careful listening \& a pleasant reception & $0.100,0.095,0.093$ & 0.096 & 1 \\
Knowledge of product & $0.391,0.395,0.393$ & 0.393 & 3 \\
Knowledge of technical issues & $0.177,0.176,0.179$ & 0.178 & 2 \\
Knowledge of trade terms & $0.245,0.247,0.248$ & 0.247 &
\end{tabular}

After examining all influencing factors for each hierarchy, we integrated them according to formula (6). The results are shown in Table 8.

Table 8. Weight and the rank after integrating all factors for all at-show strategies

\begin{tabular}{lllll}
\hline Factor & Intermediate & Weight & Integrated value & Rank \\
\hline \multirow{2}{*}{ Booth } & Location and space & 0.262 & 0.067 & 8 \\
0.256 & Booth design & 0.363 & 0.093 & 7 \\
& Public visibility & 0.376 & 0.096 & 5 \\
\hline \multirow{2}{*}{ Product } & Exhibited materials & 0.470 & 0.100 & 4 \\
0.213 & Demonstration activities & 0.530 & 0.113 & 3 \\
\hline \multirow{2}{*}{ Staff } & Active attitude & 0.087 & 0.046 & 10 \\
0.531 & Patient and careful listening \& a pleasant reception & 0.096 & 0.051 & 1 \\
& Knowledge of the product & 0.393 & 0.208 & 6 \\
& Knowledge of technical issues & 0.178 & 0.094 & 2 \\
\hline
\end{tabular}


From Table 8, a ranking was derived from among all the trade show strategies. The most important factors at trade shows are knowledge of the products and technology, knowledge regarding making deals, booth activities and demonstrations, and selection of articles exhibited.

Table 9. Weight and rank after integrating all attributes for the entire show strategies

\begin{tabular}{|c|c|c|c|c|c|}
\hline Stage & Strategy & Attribute & Weight & Integrated value & Rank \\
\hline \multirow{4}{*}{ Pre-show } & Invitation & E-mail or telephone invitation & 0.634 & 0.075 & 3 \\
\hline & 0.704 & Mailing tickets \& invitation cards & 0.366 & 0.043 & 5 \\
\hline & Advertising & News releases & 0.323 & 0.016 & 14 \\
\hline & 0.296 & Advertising & 0.677 & 0.034 & 7 \\
\hline \multirow{10}{*}{ At-show } & Booth & Location and space & 0.262 & 0.067 & 13 \\
\hline & 0.256 & Booth design & 0.363 & 0.093 & 12 \\
\hline & & Public visibility & 0.376 & 0.096 & 10 \\
\hline & Product & Exhibited materials & 0.470 & 0.100 & 9 \\
\hline & 0.213 & Demonstration activity & 0.530 & 0.113 & 8 \\
\hline & & Active attitude & 0.087 & 0.046 & 16 \\
\hline & Staff & $\begin{array}{l}\text { Patient and careful listening \& a pleasant } \\
\text { reception }\end{array}$ & 0.096 & 0.051 & 15 \\
\hline & 0.531 & Knowledge of the product & 0.393 & 0.208 & 4 \\
\hline & & Knowledge of technical issues & 0.178 & 0.094 & 11 \\
\hline & & Knowledge of trade details & 0.247 & 0.131 & 6 \\
\hline \multirow{2}{*}{ Post-show } & Sales letters & Telephone contacts or personal visits & 0.609 & 0.337 & 1 \\
\hline & Personal sales visit & Sending sales letters, catalogs, \& samples & 0.391 & 0.216 & 2 \\
\hline
\end{tabular}

Table 9 shows that "follow-up after the exhibition" (including personal contacts and sale letters) constituted the most important factor from the perspective of business visitors. "Active invitation before the exhibition" was considered to be the next most important factor in attracting business visitors at a trade show. As for at-show strategies, staff knowledge of the product and trade details were the most important factors.

\section{Conclusions}

This research was based mainly on a model of FAHP to evaluate the importance of trade show strategies from the perspective of business visitors. Following previous studies, this paper classified trade show marketing strategies into three categories: pre-, at-, and post-show. The results showed that post-show strategies played the most important role in causing business visitors to select a supplier from a trade show, followed by at-show strategies. This finding is somewhat different from those of the many studies that have focused on at-show strategies alone (Gopalakrishna \& Lilien, 1995; Rosson \& Seringhaus, 1995; Seringhaus \& Rosson, 2001; Li, 2007). We suggest that businesses put more effort into attracting business visitors who have shown an interest in trade shows.

Regarding at-show strategies, the results showed that the professional capabilities of the exhibitors was the factor that had the greatest impact in getting orders from business visitors, followed by product displays. The location and size of booths were the least important factors. In terms of the exhibited articles, products and demonstration activities were also important. For staff at trade shows, knowledge of the product, technology, and trade terms is also crucial. This result indicates that experienced staff or extensive training before trade shows are necessary to attract business visitors. Thus, staff expertise is the first major factor to be considered before trade shows. Second, to attract customers or potential customers, adequate products should be chosen to exhibit to attract business visitors. Also, active demonstrations in the booth may have a significant impact on trade show performance.

In conclusion, a successful trade show requires the careful management of many strategies. Under conditions of resource constraints, focusing on activities according to customers' priorities can effectively improve the outcome and performance of participation at a trade show. This study was conducted with businesses in Taiwan and the sample size was small. Further research is required to enlarge the sample size and to cover enterprises of different operational scales and from other industries. 


\section{References}

Bellizzi, J. A., \& Lipps, D. J. (1984). Managerial guidelines for trade show effectiveness. Industrial Marketing Management, 13(1), 49-52. http://dx.doi.org/10.1016/0019-8501(84)90008-7

Bello, D. C., \& Lohtia, R. (1993). Improving trade show effectiveness by analyzing attendees. Industrial Marketing Management, 22(4), 311-318. http://dx.doi.org/10.1016/0019-8501(93)90027-5

Bello, D. C. (1992). Industrial buyer behavior at trade shows: Implications for selling effectiveness. Journal of Business Research, 25, 59-80. http://dx.doi.org/10.1016/0148-2963(92)90005-V

Blythe, J. (2002) Using trade fairs in key account management. Industrial Marketing Management, 31(7), 627-635. http://dx.doi.org/10.1016/S0019-8501(02)00183-9

Bonoma, T. V. (1983). Get more out of your trade shows. Harvard Business Review, 61, 75-83.

Browning, J. M., \& Adams, R. J. (1988). Trade shows: an effective promotional tool for the small industrial business. Journal of Small Business Management, 26, 31-36.

Buckley, \& James J. (1985). Fuzzy Hierarchical Analysis. Fuzzy Sets and Systems, 17, 233-247. http://dx.doi.org/10.1016/0165-0114(85)90090-9

Chen, C. T. (2000). Extensions of TOPSIS for group decision-making under fuzzy environment. Fuzzy Sets and Systems, 114(1), 1-9. http://dx.doi.org/10.1016/S0165-0114(97)00377-1

Dekimpe, M. G., Francois, P., Gopalakrishna, S., \& Bulte, C. (1997). Generalizing about trade show effectiveness: A cross-national comparison. Journal of Marketing, 61(4), 55-64.

Dubois, D., \& Prade, H. (1980). Fuzzy sets and systems: theory and applications. New York. NY: Academic Press.

Godar, S. H., \& O'Connor, P. J. (2001). Same time next year-buyer trade show motives. Industrial Marketing Management, 30, 77-86. http://dx.doi.org/10.1016/S0019-8501(99)00100-5

Gopalakrishna, S., \& Lilien, G. L. (1995). A three-stage model of industrial trade shows performance. Marketing Science, 14(1), 22-42.

Gopalakrishna, S., \& Williams, J. D. (1992). Planning and performance assessment of industrial trade shows: An exploratory study. International Journal of Research in Marketing, 9(3), 207-224. http://dx.doi.org/10.1016/0167-8116(92)90018-G

Gopalakrishna, S., Lilien, G. L., Williams, J. D., \& Sequeira, I. K. (1995). Do trade shows pay off? The Journal of Marketing, 59(3), 75-83.

Hansen, K. (2004). Measuring performance at trade shows scale development and validation. Journal of Business Research, 57, 1-13. http://dx.doi.org/10.1016/S0148-2963(02)00269-2

Herbig, P. A., Palumbo, F., \& O’Hara, B. (1996). Differences in trade show behavior between manufacturers and service-oriented firms. Journal of Professional Services Marketing, 14(2), 55-78.

Jackson Jr., D. W., Keith, J. E., \& Burdick, R. K. (1987). The relative importance of various promotional elements in different industrial purchase situations. Journal of Advertising, 16(4), 25-33.

Kerin, R. A., \& Cron, W. L. (1987). Assessing trade show functions and performance: An exploratory study. The Journal of Marketing, 51(3), 87-94.

Kotler, P. (2000). Marketing Management Millenium Edition (10th ed.). NY: Prentice Hall.

Laarhoven, P. J. M., \& Pedrycz, W. (1983). A fuzzy extension of Saaty's priority theory. Fuzzy Sets and Systems, 11(3), 229-241. http://dx.doi.org/10.1016/S0165-0114(83)80082-7

Lee, C. H., \& Kim, S. Y. (2008). Differential effects of determinants on multi-dimensions of trade show performance: By three stages of pre-show, at-show, and post-show activities. Industrial Marketing Management, 37(7), 784-796. http://dx.doi.org/10.1016/j.indmarman.2008.01.006

Li, L. (2007). Marketing resources and performance of exhibitor firms in trade shows: A contingent resource perspective. Industrial Marketing Management, 36(3), 360-370.

Miller, G. A. (1956). The magical number seven plus or minus two: Some limits on our capacity for processing information. Psychological Review, 63(2), 81-96.

Munuera, J. L., \& Ruiz, S. (1999). Trade fairs as services: a look at visitors' objectives in Spain. Journal of 
Business Research, 44, 17-24. http://dx.doi.org/10.1016/S0148-2963(97)00174-4

O’Hara, B., Palumb, F., \& Herbig, P. (1993). Industrial trade shows abroad. Industrial Marketing Management, 22(3), 233-237. http://dx.doi.org/10.1016/0019-8501(93)90010-5

Rosson, P. J., \& Seringhaus, F. H. R. (1995). Visitor and exhibitor interaction at industrial trade fairs. Journal of Business Research, 32, 81-90. http://dx.doi.org/10.1016/0148-2963(94)00012-4

Saaty, T. L. (1980). The Analytic Hierarchy Process. New York, NY: McGraw-Hill.

Sharland, A., \& Balogh, P. (1996). The value of nonselling activities at international trade shows. Industrial Marketing Management, 25(1), 59-66. http://dx.doi.org/10.1016/0019-8501(95)00065-8

Shoham, A. (1992). Selecting and evaluating trade show. Industrial Marketing Management, 22(5), 335-341. http://dx.doi.org/10.1016/0019-8501(92)90044-T

TAITRA (Taiwan External Trade Development Council). (2013). Computex Taipei 2013. Retrieved from http://www.computextaipei.com.tw/

Tanner, Jr. J. F., \& Chonko, L. B. (1995). Trade show objectives, management, and staffing practices. Industrial Marketing Management, 24(4), 257-264. http://dx.doi.org/10.1016/0019-8501(94)00082-8

Tanner, Jr. J. F. (2002). Leveling the playing field: factors influencing trade show success for small companies. Industrial Marketing Management, 31(3), 229-239. http://dx.doi.org/10.1016/S0019-8501(00)00132-2

Teng, J. Y., \& Tzeng, G. H. (1993). Transportation investment project selection with fuzzy multiobjectives. Transportation Planning and Technology, 17(2), 91-112.

Tzeng, M. L., \& Lin, Y. S. (2008). Selection of competitive advantages in TQM implementation using fuzzy AHP and sensitivity analysis. Asia Pacific Management Review, 13(3), 583-599.

Wen, Y., \& Duan, W. (2008). Trade Show Marketing. Taipei: TAITRA.

Wikipedia. (2013). Trade fair. Retrieved on Sep. 20, 2012 from http://en.wikipedia.org/wiki/Trade_fair

Yao, W. (2007). Bible for Exhibitions: Winning Strategies for Attending Trade Shows. Taipei: China Productivity Center.

Zadeh, L. A. (1965). Fuzzy sets. Information and Control, 8(3), 338-353. http://dx.doi.org/10.1016/S0019-9958(65)90241-X

\section{Copyrights}

Copyright for this article is retained by the author(s), with first publication rights granted to the journal.

This is an open-access article distributed under the terms and conditions of the Creative Commons Attribution license (http://creativecommons.org/licenses/by/3.0/). 